\title{
Evaluation of the antinociceptive effect of xylazine and it's interaction with metoclopramide in the acute pain model in mice
}

\author{
Kh.A. Shaban ${ }^{1}$, M.H. Ibrahim² ${ }^{2}$ and G.A. Faris ${ }^{3}$ \\ Department of Physiology, Biochemistry and Pharmacology, College of Veterinary Medicine, Mosul University, Mosul, Iraq \\ Email: ${ }^{1}$ akhalid18@yahoo.com, ${ }^{2}$ munaalzubaidy77@ yahoo.com, ${ }^{3}$ ghadafaris2018@ gmail.com
}

(Received September 5, 2019; Accepted October 27, 2019; Available online July 23, 2020)

\begin{abstract}
The study was designed to qualitative and quantitative evaluation of the antinociceptive effect of metoclopramide and xylazine each alone or as a concomitant administration in mice. Adult albino Swiss mice weighing 20-30 mg used in all experiments. By using the hot plate test, the individual analgesic dose (ED50) of metoclopramide and xylazine detected depending on the up and down method. Isobolographic analysis used to evaluate the type of interaction between two drugs at the ratio 0.5:0.5 of individual ED 50 for each drug at the level of antinociception effect. Simultaneously administration of the double dose of individual EDs0 and low doses (sedative, non-analgesic doses) of both drugs, also evaluated at the level of central and visceral analgesia using a hot plate and writhing response test respectively. The individual ED50 of xylazine and metoclopramide was 10.8 and $25.6 \mathrm{mg} / \mathrm{kg}$ IP respectively. A synergistic interaction at the level of analgesia explored between two drugs at ratio 0.5:0.5 which represented as decreased in ED50 of metoclopramide and xylazine by 58.75 and $58.15 \%$ respectively. The animal suffered from only slight sedation and docile. Simultaneously IP administration of xylazine and metoclopramide at double dose of ED 50 for each drug-induced significant increase in latency time of thermal response, as well as a significant decrease in writhes number, which induced by acetic acid in comparison with control groups. The percentage of analgesia at sub analgesic doses of a concomitant administration of both drugs was $100 \%$ in comparison with each drug alone. These results suggested safe and good use of both drugs in veterinary medicine.
\end{abstract}

Keywords: Xylazine, Metoclopramide, Analgesia, Hot plate, Acetic acid

DOI: $10.33899 /$ ijvs.2019.126070.1226, (O2020, College of Veterinary Medicine, University of Mosul.

This is an open access article under the CC BY 4.0 license (http://creativecommons.org/licenses/by/4.0/).

$$
\begin{aligned}
& \text { تقيم التأثير المسكن للألم للزيلازين وتداخله مع الميتوكلوبرومايد في نموذج الألم الحاد في الفئران } \\
& \text { خالد احمد شعبان، منى حازم البرا هيم و غادة عبدالمنعم فارس } \\
& \text { فرع الفسلجة والكيمياء الحياتية والأدوية، كلية الطب البيطري، جامعة الموصل، الموصل، العراق }
\end{aligned}
$$

صُمِمَتْ الدر اسة لتقييم الفعل المسكن لعقار المينوكلوبرومايد و الزيلازين تقيما كميا ونو عيا عند إعطائهما كل لوحده أو معا للحيوان

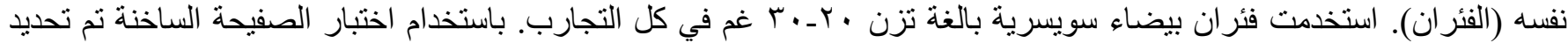

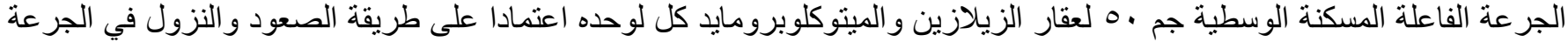

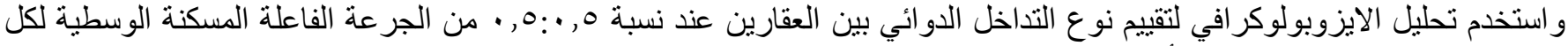

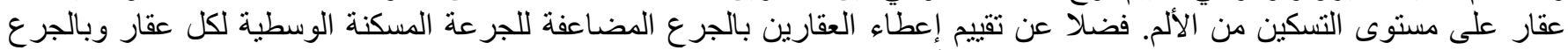

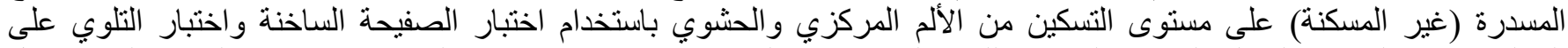

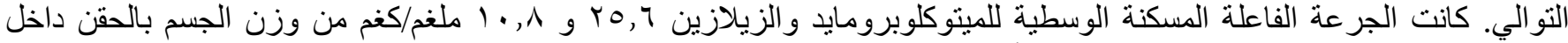

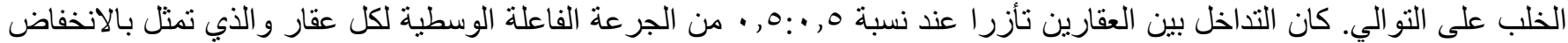




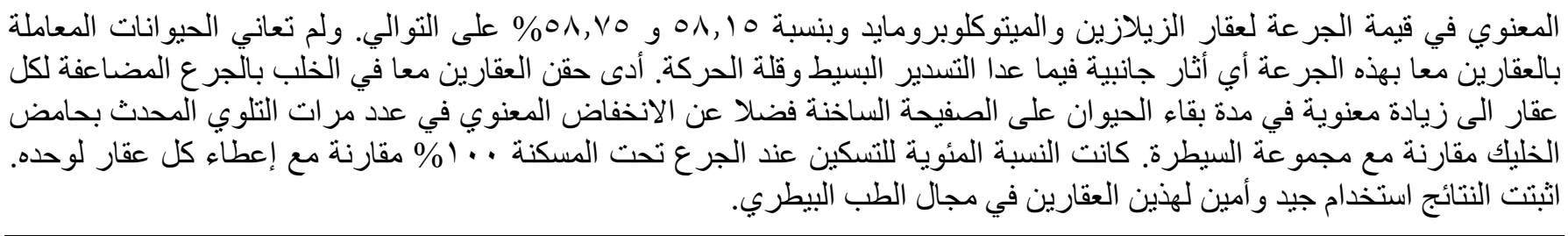

\section{Introduction}

Metoclopramide is a benzamine derivative (1), used in humans and animals $(2,3)$, as centrally acting antiemetic and reduces stomach movement. These effects related to its centrally antagonizing of dopamine $\mathrm{D}_{2}$-receptors antagonist, and serotonergic effects $5 \mathrm{HT}_{3}$ (4). Indirect cholinergic action also involved in this mechanism (5). The analgesic effect of metoclopramide was reported recently in humans $(6,7)$, dogs (8), rats and mice (9). The mechanism of antinociception effect by metoclopramide remain is unknown yet. Xylazine is one of alpha-2 adrenergic receptor agonists, widely used in veterinary practice as sedative, analgesic and muscle relaxant $(10,11)$. Xylazine also can be used as pre-anesthetic with ketamine to produce balance anesthetic (12,13). Different combinations of xylazine with other analgesic were evaluated in different animal models to improve the quality of analgesic properties and minimizing the side effects. Combination of xylazine with dipyrone (14) or tramadol (15) in mice and in chicks (16) or with chlorpromazine in sheep (17) and chicks (18), produced safe and effective analgesia at low doses of each drug (synergistic antinociceptive effect).

However, the combination of xylazine and metoclopramide was not evaluated in previous studies, so the purpose of current study was to qualitative and quantitative evaluation of the analgesic effect of metoclopramide and xylazine each alone or as a combination. the type of interaction between two drugs also evaluated in mice by using two models of acute pain induction, hot plate (central) and writhing response (peripheral) $(19,20)$.

\section{Materials and methods}

\section{Animals}

All experiments were carried out by using male and female albino Swiss mice weighing 20-30 g. The animals were housed in the animal house of the college of veterinary medicine, University of Mosul. They were maintained under standard conditions with 10/14 hrs. light/dark cycle, at $22 \pm 2^{\circ} \mathrm{C}$ room temperature. Food and water available at the laboratory. The scientific committee of the department of physiology, biochemistry and pharmacology at the college of veterinary medicine has reviewed and approved the protocol of this study. The doses of metoclopramide (pure powder Vainkunth Co., India) and xylazine $(20 \mathrm{mg} / \mathrm{ml}$ injectable solution, Holland $)$ were dissolved in physiological saline solution at volume of injection $5 \mathrm{ml} / \mathrm{kg}$ body weight, IP

\section{Methods}

By using the up-and-down method (21) the median effective analgesic doses of metoclopramide and xylazine (alone or as a combination) were detected in mice by using a hot plate (thermal method). The initial dose was determined based on experience and previous studies $(22,23)$. The increasing and decreasing in the later dose of each drug was at a constant value. The analgesic effect was assessed by placing the mice on a hot plate (Heidolph Me, Germany, Hei-standard Co. at $56^{\circ} \mathrm{C}$ ), the time between placing the mice on the hot plate and licking of fore or hind paw or/and jumping off from the surface was recorded as the response in seconds. Only mice that response to nociceptive response within 30 seconds was used in this study, the cut off time was 30 seconds to avoid any thermal injury to the paw (19), animals were used only once. The response was measured before (baseline) and at 15 minutes after injected of each drug doses.

\section{Analgesic interaction between metoclopramide and xylazine}

In order to evaluate the type of interaction between metoclopramide and xylazine. The first animal was simultaneously injected with initial dose of metoclopramide and xylazine at $12.8 \mathrm{mg} / \mathrm{kg}$ i.p and $5.4 \mathrm{mg} / \mathrm{kg}$ i.p respectively at ratio $0.5: 0.5$ of ED50 for each drug. The type of interaction was detected by isobolographic analysis and $Y$ interaction index (24-26). A straight line drawled between the EDs0 of metoclopramide (pointed on $\mathrm{x}$ axis) and that for xylazine (pointed on y axis). The EDso value of combination $(0.5: 0.5)$ also pointed, when this value detects under the straight diagonal line, the interaction is synergistic, while falling this value on/and above the line, the interaction are additive and antagonized respectively. The addition interaction index was calculated by using equation: $\mathrm{Y}=\mathrm{da} / \mathrm{Da}+\mathrm{db} / \mathrm{Db}$.

Where: $(\mathrm{Da}$ and $\mathrm{Db})$ are individual $\mathrm{ED}_{50}$ of metoclopramide and xylazine respectively, while the (da and $\mathrm{db}$ ) represent the combination doses that produce the same effect (analgesic). When the value of $Y=1$ its additive 
(no interaction), $\mathrm{Y}<1$ synergism (supra additive) and $\mathrm{Y}>1$ its antagonism (sub additive), this is an interaction index.

\section{Acetic acid inducing writhing reflex (chemical test) and hot plate (thermal test) at double doses of ED50 of metoclopramide and xylazine}

Mice were used in this experimental divided into four groups (5 animals for each group), group I and Ш injected with normal saline while group $\Pi$ and IV injected with metoclopramide and xylazine at $51.2 \mathrm{mg} / \mathrm{kg}$ b.w i.p and $21.6 \mathrm{mg} / \mathrm{kg}$ b.w i.p respectively (double dose of $\mathrm{ED}_{50}$ ).

Animals in group I and $\Pi$ placed on hot plate before and 15 minute after injection of normal saline and drugs for calculation of latency time, while group $\amalg$ and IV were received normal saline and drugs 15 minute before injected with $1 \%$ acetic acid at volume $0.1 \mathrm{ml} / 10 \mathrm{~g}$ b.w i.p to induce writhing response and calculate number of writhing which recorded within 30minute after injection of acetic acid (27).

Estimation percentage of analgesia of pain in subanalgesic doses of metoclopramide and xylazine each alone or in combination by thermal method (hot plate)

In this experimental, mice divided into three groups, each group consist of 5 animals, group I injected with metoclopramide $10 \mathrm{mg} / \mathrm{kg}$ b.w i.p, group $\Pi$ injected with xylazine $2 \mathrm{mg} / \mathrm{kg}$ b.w i.p and group Ш injected with metoclopramide and xylazine at $10 \mathrm{mg} / \mathrm{kg}$ b.w i.p and

$2 \mathrm{mg} / \mathrm{kg}$ b.w i.p respectively. animals placed on hot plate before and 15 minutes after injection of drugs for calculate of latency time (19).

\section{Data analysis}

The data for latency time (thermal test) were statistically subjected to unpaired $\mathrm{t}$-test, while number of writhing were analyzed by Mann Whitney u-test, and for percentage of analgesia (hot plate) by fisher test (28). The level of significant was $\mathrm{P}<0.05$.

\section{Results}

In the present study the dose that produce $50 \%$ of analgesic effect in mice for metoclopramide and xylazine induced was 25.6 and $10.8 \mathrm{mg} / \mathrm{kg}$, respectively by using up and down method (Table 1).while concomitant injected mice with a combination of metoclopramide and xylazine at ratio 0.5:0.5 of $\mathrm{ED}_{50}$ for each, was markedly reduced the value of $\mathrm{ED}_{50}$ to 10.56 and $4.52 \mathrm{mg} / \mathrm{kg}$, respectively (Table 1). The mice that injected with metoclopramide and xylazine were suffered from signs of slight sedation and docile.

Table1: Determination of median effective doses of metoclopramide and xylazine

\begin{tabular}{lcccc}
\hline \multirow{2}{*}{ Variable } & \multirow{2}{*}{ Metoclopramide } & \multirow{2}{*}{ Xylazine } & \multicolumn{2}{c}{ Metoclopramide and Xylazine at ratio 0.5:0.5 } \\
\cline { 3 - 4 } & & & Metoclopramide & Xylazine \\
\hline ED $_{50} 5.6 \mathrm{mg} / \mathrm{kg}$ & $10.8 \mathrm{mg} / \mathrm{kg}$ & $10.56 \mathrm{mg} / \mathrm{kg}$ & $4.52 \mathrm{mg} / \mathrm{kg}$ \\
Range of doses used & $20-30 \mathrm{mg} / \mathrm{kg}$ & $10-20 \mathrm{mg} / \mathrm{kg}$ & $9.6-12.8 \mathrm{mg} / \mathrm{kg}$ & $4.15-5.4 \mathrm{mg} / \mathrm{kg}$ \\
Initial dose & $20 \mathrm{mg} / \mathrm{kg}$ & $20 \mathrm{mg} / \mathrm{kg}$ & $12.8 \mathrm{mg} / \mathrm{kg}$ & $5.4 \mathrm{mg} / \mathrm{kg}$ \\
Last dose & $30 \mathrm{mg} / \mathrm{kg}$ & $10 \mathrm{mg} / \mathrm{kg}$ & $12.8 \mathrm{mg} / \mathrm{kg}$ & $5.4 \mathrm{mg} / \mathrm{kg}$ \\
Number of mice used & $5(\mathrm{OXOOX})^{\mathrm{a}}$ & $5(X O X X X)^{\mathrm{a}}$ & $5(X O X O X)^{\mathrm{a}}$ & $5(X O X O X)^{\mathrm{a}}$ \\
Increase or decrease in dose & $5 \mathrm{mg} / \mathrm{kg}$ & $5 \mathrm{mg} / \mathrm{kg}$ & $3.2 \mathrm{mg} / \mathrm{kg}$ & $1.25 \mathrm{mg} / \mathrm{kg}$ \\
Percentage of decrease in ED & & & $58.75 \%$ & $58.15 \%$ \\
Y value & & & 0.83 & 0.83 \\
\hline
\end{tabular}

${ }^{\mathrm{a}} \mathrm{x}$ - analgesia; o - no analgesia. The ED50 were determined by the up and down method.

By using Isobolographic analysis, pointed the value of $\mathrm{ED}_{50 \mathrm{~s}}$ for each alone, then detected the situation of $\mathrm{ED}_{50}$ value for a combination, this value was fallen down under the diagonal line that connect the $\mathrm{ED}_{50 \mathrm{~s}}$ for each drug alone that revealed a synergistic antinociceptive interaction in mice (Figure 1).

Furthermore, calculate the $\mathrm{Y}$ value from equation of interaction index, it was lower than $1(0.83)$ that indicated the synergism interaction $(\mathrm{Y}<1)$.

In second experiment we evaluated the peripheral (chemical test of acetic acid) and central (thermal test) antinociception effect for further examine the synergistic interaction between metoclopramide and xylazine given as combination (doubling of $\mathrm{ED}_{50}$ for each drug), whereas significantly increased the latency time of thermal response and significant decreased in writhing number of acetic acids in compares with control groups (Table 2).

Evaluation of analgesia percentage of pain by administration of sub analgesic (sedated) dosages of metoclopramide $(10 \mathrm{mg} / \mathrm{kg}$ i.p) and xylazine $(2 \mathrm{mg} / \mathrm{kg}$ i.p) each alone or in combination in mice. whereby was analgesia percentage of pain $0 \%$ when administered each drug alone while analgesia percentage of pain $100 \%$ when administered two drugs in combined form (Table 3 ). 


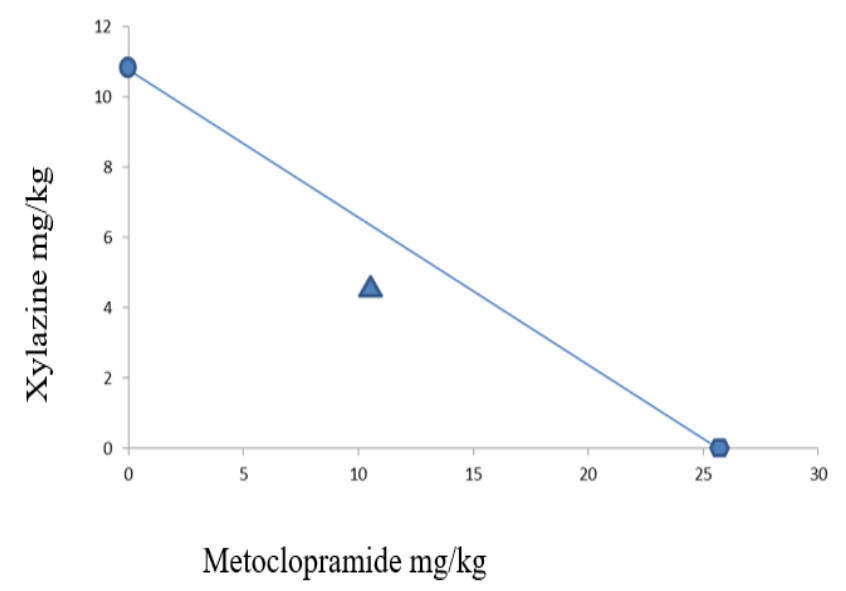

Figure 1: Isobolographic analysis of interaction between metoclopramide and xylazine at ratio 0.5:0.5 in mice. The diagonal line joints the individual ED50s of metoclopramide and that of xylazine, the triangle points which represent 0.5:0.5 of ED 50 combination of two drugs, located below the diagonal line, indicate synergism interaction. xylazine at dose $10.8 \mathrm{mg} / \mathrm{kg}$ IP, metoclopramide at dose $25.6 \mathrm{mg} / \mathrm{kg} \mathrm{IP}$, xylazine and metoclopramide at ratio 0.5:0.5.
Table 2: Metoclopramide and xylazine analgesia following combined administration in mice

\begin{tabular}{|c|c|c|}
\hline Analgesic test & $\begin{array}{l}\text { Saline } \\
\text { control }\end{array}$ & $\begin{array}{l}\text { Analgesic } \\
\text { combination }\end{array}$ \\
\hline $\begin{array}{l}\text { Hot plate } \\
\text { (latency in seconds) }\end{array}$ & $0.2 \pm 0.2$ & $11.6 \pm 0.8 *$ \\
\hline $\begin{array}{l}\text { Acetic acid } \\
\text { (Writhing / } 30 \text { minutes) }\end{array}$ & $43.5 \pm 3.27$ & $0.0 \pm 0.0 *$ \\
\hline \multicolumn{3}{|c|}{$\begin{array}{l}\text { Values are Mean } \pm \text { SE of } 5 \text { mice / group. Analgesi } \\
\text { evaluated in mice } 15 \text { minutes after administration of botl } \\
\text { drugs. } \\
* \text { Significantly different from the respective control value a } \\
\mathrm{P}<0.05 \text {. }\end{array}$} \\
\hline
\end{tabular}

\section{Discussion}

In this study we explored the antinociceptive effect of xylazine alone or as a combination with metoclopramide in mice. Xylazine is an alpha-2 agonist which induced analgesia by inhibit NE and dopamine reuptake in CNS, which in turn produce CNS depression $(10,28)$. Metoclopramide is well known as antiemetic, but recently reported as analgesic in man $(6,7), \operatorname{dog}(8)$, rat (9) and mice, alone or as a combination with other drugs as ketamine (3), tramadol (29) and diphenhydramine (30).

Table 3: Percentage of analgesia for each drug alone or as a combination by using hot plate test

\begin{tabular}{lccc}
\hline Drug and dose & $\begin{array}{c}\text { Latency time } \\
\text { (base line) }\end{array}$ & $\begin{array}{c}\text { Latency time } \\
\text { (after 15 minutes of injection) }\end{array}$ & $\begin{array}{c}\text { percentage of analgesia } \\
\text { (Hot plate test) }\end{array}$ \\
\hline Metoclopramide 10 mg/kg IP & $8.8 \pm 1.24$ & $7.8 \pm 0.73$ & $0 \%$ \\
Xylazine 2 mg/kg IP & $8.2 \pm 1.01$ & $7 \pm 0.70$ & $0 \%$ \\
Metoclopramide 10 mg/kg IP & $6.7 \pm 0.42$ & $15.85 \pm 0.45 *$ & $100 \% *$ \\
and Xylazine 2 mg/kg IP & & & \\
\hline
\end{tabular}

* Significantly different from each drug alone $(\mathrm{P}<0.05)$.

Dependent on up and down method (21), $\mathrm{ED}_{50}$ for analgesia of metoclopramide and xylazine was evaluated using hot plate test, as a thermal test for detecting central pain (31), while visceral pain was detected using writhing test as chemical test (32). $\mathrm{ED}_{50}$ of xylazine and metoclopramide was 10.8 and $25.6 \mathrm{mg} / \mathrm{kg}$, IP respectively. Dependent on up and down method, this value was in agreement with previous reports for xylazine (13) and that for metoclopramide (3). The type of drug combination may be additive, synergism or antagonism (23-25).

The present study revealed that the type of interaction of xylazine and metoclopramide as a combination was synergistic at fixed ration 0.5:0.5 of individual ED50 for each at the level of analgesia, we supported this finding by calculate the value of $\mathrm{Y}$ interaction index, which was lower than 1 (23-25), this finding similar to the previous studies of other combinations as ketamine with metoclopramide (3), xylazine with tramadol (15) and metoclopramide with diphenhydramine (30) in mice, as all of them was synergistic interaction at level of analgesia. The synergistic interaction between xylazine and metoclopramide may be attributed to effect of each on different receptors (pharmacodynamics). Xylazine acts as strong central alpha 2 agonist via stimulating central $\alpha 2$ pre-receptors leading to decrease release NE and dopamine in CNS $(10,28)$, which induced synergistic analgesic effects with other drugs as tramadol (15) and dipyrone (14), while metoclopramide act as analgesic by effect on D2-receptors as antagonist, which related with opioid system without interaction with opioid receptors (33), metoclopramide also increase the level of prolactin hormone which related with opioid system $(34,35)$. Other suggested mechanisms for analgesic effect of 
metoclopramide that correlate with its interference with transport of $\mathrm{Ca}^{+}$cross the cell membrane $(35,36)$, as well as act as serotonin agonist (4).

Pharmacokinetic may be suggested as another mechanism for explain the synergistic interaction between metoclopramide and xylazine, as metoclopramide metabolized in liver by cytochrome p450 2D6 (37), in addition metoclopramide inhibit same enzyme, this may prolong the duration of action of drug in the body (38-40). Xylazine also metabolized in the liver by cytochrome $\mathrm{p} 450$ $3 \mathrm{~A}$ (41) which inhibited by xylazine and then the duration of action of xylazine and metoclopramide well be increased. This suggested mechanism may also explain the visceral antinociceptive effect of the same combination at double $\mathrm{ED}_{\mathbf{5 0}}$ of each drug, this visceral analgesic effect in agreement with that previous studies as a combination of ketamine with metoclopramide (3) and metoclopramide with diphenhydramine (30) in mice. A good and safe analgesic effect without overt sedative effect also reported in this study using sedative non-analgesic doses of both drugs as a combination. This additional support the synergistic effect between two drugs by mechanism which may be similar to that explain above. All results in the present study especially the synergistic combination of both drugs at sedative doses not reported previously.

\section{Conclusion}

In conclusion the present study suggests that the synergism combination between xylazine and metoclopramide at level of central and visceral analgesia in mice. The combination of both drugs at low doses produce good and safe analgesia, which can be useful in veterinary medicine.

\section{Acknowledgements}

The research was backed by the University of Mosul, Mosul, Iraq, and College of Veterinary Medicine, Department of Physiology, Biochemistry and Pharmacology.

\section{Conflict of interests}

The authors declares no conflict of interest

\section{References}

1. Fischer J, Gere A. Timing of analog research in medicinal chemistry. Drug Discov Dev. 2006;199. Doi: 10.1002/0471780103\#page=216

2. DiPiro J, Schwinghammer T, DiPiro C. Pharmacotherapy handbook. New York: McGraw-Hill Companies; 2009; p. 271
3. Mohammad FK, Al-Baggou BK, Naser AS. Antinociception by metoclopramide, ketamine and their combinations in mice. Pharmacol Reports. 2012;64(2):299-304. Doi: 10.1016/ S1734-1140(12)70768-5

4. Fisher AA, Davis MW. Serotonin syndrome caused by selective serotonin reuptake-inhibitors metoclopramide interaction. Ann Pharmacother. 2002;36(1):67-71. Doi: 10.1345/aph.1A161

5. Chemnitius JM, Haselmeyer KH, Gonska BD, Kreuzer H, Zech R. Indirect parasympathomimetic activity of metoclopramide: Reversible inhibition of cholinesterase from human central nervous system and blood. Pharmacol Res. 1996;34(1-2):65-72. Doi: 10.1006/phrs.1996.9999

6. Cicek M, Karcioglu O, Parlak I, Ozturk V, Duman O, Serinken M. Prospective, randomized, double blind, controlled comparison of metoclopramide and pethidine in the emergency treatment of acute primary vascular and tension type headache episodes. Emerg Med J. 2004;21(3):323-6. Doi: 10.1136/emj.2002.000356

7. Afsargharehbagh R, Mosaed S, Nasiri A, Afshari M, Moosazadeh M. Comparison of the effects of intravenous metoclopramide and ondansetron on prevention of nausea and vomiting after cesarean section. Biomed Res. 2018;29(15):3043-3046. Doi: 10.4066/biomedicalresearch.29-18-70

8. Tavakoli A, Kazemi Mehrjerdi H, Haghighi A. Analgesic effects of metoclopramide following conventional ovariohysterectomy in bitches. Iran J Vet Surg. 2009;4(1-2):77-84.

9. Ceyhan A, Ustun H, Altunatmaz K, Ide T, Unal N. Is Metoclopramide an alternative to tramadol in management of post- operative pain? An experimental study. J Vet Med Ser A. 2005;52(5):249-53. Doi: 10.1111/j.1439-0442.2005.00719.x

10. Lumb W V, Jones EW, Thurmon JC, Tranquilli WJ, Benson GJ. Lumb and Jones' veterinary anesthesia. New York: Williams and Wilkins; 1996; p.48

11. Plumb DC. Veterinary Drug Handbook Eighth Edition [Internet]. $2015 ;$ p. 342

https://www.wiley.com/en-gb/Plumb\%27s+Veterinary+Drug+Handbook\%3A+Desk\%2C+9th+Edition-p-9781119344452\%0A www blackwellpublishing.com/Vet/

12. Bharathidasan $\mathrm{M}$, Thirumurugan $\mathrm{R}$, William BJ, George RS, Arunprasad A, Kannan TA, et al. Xylazine-ketamine immobilization and propofol anesthesia for surgical excision of sebaceous adenoma in a jaguar (Panthera onca). Vet World. 2014;7(11):986-90. Doi: $10.14202 /$ vetworld.2014.986-990

13. El-Sherif M. Optimization of xylazine-ketamine anesthetic dose in mice with chronic liver injury. Egypt Acad J Biol Sci B Zool. 2019;11(1):13-8.

14. Mohammad FK, Faris GM, Rhayma MSH. Analgesic and behavioral effects of xylazine - dipyrone combination in mice. Iraqi J Vet Sci. 2001;14(2):183-189.

15. Taqa GA. Synergism of the analgesic activities of tramadol with $\alpha 2$ adrenoreceptor agonist xylazine in mice. Iraqi $\mathrm{J}$ Vet Sci. 2012;26(2):109-13. Doi: $10.33899 /$ ijvs.2012.67485

16. Shaban KA, Faris GA. Evaluation of the analgesic effect of xylazine, dipyrone and tramadol in a single dose or as a combination in chicks. Al-Anbar J Vet Sci. 2012;5(2):197-210.

17. Abdullah MA, Faris GAM. Evaluation the sedative and analgesic effect of xylazine and chloropromazine alone or as a combination in sheep. Al-Anbar J Vet Sci. 2013;6(1):109-18.

18. Hasan MM. Evaluating the sedative and analgesic effects of xylazine and its interaction with chlorpromazine in chicks. Iraqi $\mathbf{J}$ Vet Sci. 2018;32(2):9-3. Doi: 10.33899/ijvs.2019.153871

19. Acharya SD, Ullal P, Padiyar S, Rao YD, Upadhyaya K, Pillai D. Analgesic effect of extracts of Alpiniagalanga rhizome in mice. $\mathrm{J}$ Chinese Integr Med. 2011;9(1):100-4.

20. de Campos Buzzi F, Fracasso M, Cechinel Filho V, Escarcena R, del Olmo E, San Feliciano A. New antinociceptive agents related to dihydrosphingosine. Pharmacol Reports. 2010;62(5):849-57. Doi: 10.1016/ S1734-1140(10)70344-3 
21. Dixon WJ. Efficient analysis of experimental observations. Annu Rev Pharmacol Toxicol. 1980;20(1):441-62.

Doi: 10.1146/annurev.pa.20.040180.002301

22. Arras M, Autenried P, Rettich A, Spaeni D, Rülicke T. Optimization of intraperitoneal injection anesthesia in mice: drugs, dosages, adverse effects, and anesthesia depth. Comp Med. 2001;51(5):443-56 .

23. Gonzalez C, Zegpi C, Noriega V, Prieto JC, Miranda HF. Synergism between dexketoprofen and meloxicam in an orofacial formalin test was not modified by opioid antagonists. Pharmacol Reports. 2011;63(2):433-40. 10.1016/S1734-1140(11)70509-6

24. Mohammad FK, Al-Zubaidy MHI, Alias AS. Sedative and hypnotic effects of combined administration of metoclopramide and ketamine in chickens. Lab Anim. 2007;36(4):35.

25. Puig MM, Warner W, Pol O. Intestinal inflammation and morphine tolerance alter the interaction between morphine and clonidine on gastrointestinal transit in mice. Anesthesiol J Am Soc Anesthesiol. 2000;93(1):219-30

26. Le Bars D, Gozariu M, Cadden SW. Animal model nociception. Pharmacol Rev. 2001;53:597-652.

27. Petrie A, Watson P. Statistics for veterinary and animal science. USA: Blackwell Science Ltd; 1999; pp.102-105

28. Gross ME, Booth NH. Tranquilizers, $\alpha 2$-adrenergic agonists, and related agents. Vet Pharmacol Ther. 2001;41(56):43-66.

29. Pang W, Liu YC, Maboudou E, Chen TX, Chois JM, Liao CC. Metoclopramide improves the quality of tramadol PCA indistinguishable to morphine PCA: A prospective, randomized, double blind clinical comparison. Pain Med. 2013;14(9):1426-34. Doi: 10.1111/pme.12166

30. Ai-Najmawy TA, Faris GM. Evaluation the antinociception of metoclopramide and their interaction with diphenhydramine in acute model of pain in male mice. Basrah J Vet Res. 2018;3(17):391-411.

31. Friedman BW, Esses D, Solorzano C, Dua N, Greenwald P, Radulescu R. A randomized controlled trial of prochlorperazine versus metoclopramide for treatment of acute migraine. Ann Emerg Med. 2008;52(4):399-406.
32. Salazar G, Fragoso M, Vergez L, Sergio P, Cuello D. Metoclopramide as an analgesic in severe migraine attacks: An open, single-blind, parallel control study. Recent Pat CNS Drug Discov. 2011;6(2):141-5. Doi: $10.2174 / 157488911795933947$

33. Kurtipek O, Oral M, Basar HT, Asik I, Ates Y, Kuzu I. Histopathologic changes after repetitive peridural administration of metoclopramide in dogs. Anesth Analg. 1999;88(1):100-102. Doi: 10.1213/00000539-199901000-00019

34. Lisander B. Evaluation of the analgesic effect of metoclopramide after opioid-free analgesia. $\mathrm{Br} \mathrm{J}$ Anaesth. 1993;70(6):631-3. Doi: $10.1093 / \mathrm{bja} / 70.6 .631$

35. Kandler D, Lisander B. Analgesic action of metoclopramide in prosthetic hip surgery. Acta Anaesthesiol Scand. 1993;37(1):49-53. Doi: 10.1111/j.1399-6576.1993.tb03597.x

36. Ozucelik DN, Karaca MA, Sivri B. Effectiveness of pre- emptive metoclopramide infusion in alleviating pain, discomfort and nausea associated with nasogastric tube insertion: A randomized, doubleblind, placebo- controlled trial. Int J Clin Pract. 2005;59(12):14221427. Doi: $10.1111 / \mathrm{j} .1368-5031.2005 .00712 . x$

37. Desta Z, Wu GM, Morocho AM, Flockhart DA. The gastroprokinetic and antiemetic drug metoclopramide is a substrate and inhibitor of cytochrome P450 2D6. Drug Metab Dispos. 2002;30(3):336-43. Doi: 10.1124/dmd.30.3.336

38. Brown NJ, Roberts LJ. Histamine, bradykinin, and their antagonists. Goodman Gilman's Pharmacol Basis Ther. 2001;645-67.

39. Gelotte CK, Zimmerman BA, Thompson GA. Single- dose pharmacokinetic study of diphenhydramine $\mathrm{HCl}$ in children and adolescents. Clin Pharmacol Drug Dev. 2018;7(4):400-407. Doi: $10.1002 /$ cpdd. 391

40. Lessard É, Yessine M-A, Hamelin BA, Gauvin C, Labbé L, O’Hara G. Diphenhydramine alters the disposition of venlafaxine through inhibition of CYP2D6 activity in humans. J Clin Psychopharmacol. 2001;21(2):175-84.

41. Veilleux-Lemieux D, Castel A, Carrier D, Beaudry F, Vachon P. Pharmacokinetics of ketamine and xylazine in young and old SpragueDawley rats. J Am Assoc Lab Anim Sci. 2013;52(5):567-70. 